\title{
F-Box Only Protein 38
}

National Cancer Institute

\section{Source}

National Cancer Institute. F-Box Only Protein 38. NCI Thesaurus. Code C114612.

F-box only protein 38 (1188 aa, $134 \mathrm{kDa}$ ) is encoded by the human FBXO38 gene. This protein may play a role in ubiquitination. 